https://doi.org/10.5800/GT-2017-8-3-0291

\title{
ALLOCHTHONOUS MARBLES IN HIGH-GRADE METAMORPHIC TERRANES (A CASE STUDY OF OLKHON TERRANE, WEST BAIKAL AREA, RUSSIA)
}

\author{
E. V. Sklyarov ${ }^{1}$, A. V. Lavrenchuk ${ }^{2}$ \\ ${ }^{1}$ Institute of the Earth's Crust, Siberian Branch of RAS, Irkutsk, Russia \\ ${ }^{2}$ V.S. Sobolev Institute of Geology and Mineralogy, Siberian Branch of RAS, Novosibirsk, Russia
}

For citation: Sklyarov E.V., Lavrenchuk A.V., 2017. Allochthonous marbles in high-grade metamorphic terranes (a case study of Olkhon terrane, West Baikal area, Russia). Geodynamics \& Tectonophysics 8 (3), 561-563. doi:10.5800/GT2017-8-3-0291.

Marbles are common constituents of high-temperature (HT) metamorphic terranes and shields. They have been traditionally considered as indicators of sedimentary or volcanic origin of related rocks involved into metamorphism which erases the primary features of the protoliths. This approach is correct in most cases, but carbonate and silicate-carbonate rocks, which often make linear bodies, may be allochthonous in some structurally and compositionally complex metamorphic terranes, as in the case of the Olkhon terrane.

The Olkhon metamorphic terrane is a part of the Early Palaeozoic accretionary-collisional system in the northern Central Asian Orogenic Belt (CAOB). The terrane was produced by an Ordovician collision (470$460 \mathrm{Ma}$ ) as a collage of numerous chaotically mingled tectonic units that are composed of rocks of different ages (1870-1830, 840, 800, 640, 545, and 500$490 \mathrm{Ma}$ ) originated in different tectonic settings. All pre-collisional complexes in the Olkhon terrane have their analogs among the rocks formed during main events in the northern CAOB history [Donskaya et al., 2017]. The terrane history comprised several stages of thrusting, doming, and strike-slip faulting accompanied by high-temperature metamorphism and mafic and granitic magmatism [Fedorovsky, Sklyarov, 2010]. The processes of strike-slip tectonics were the most vigorous and diverse and defined the general structure of the Olkhon region with packages of tectonic units varying in composition, morphology, and structure. The tectonic units are separated by ductile shear zones of blastomylonites. The terrane has a complex mosaic structure but generally splits into the Southeastern and Northwestern major zones with (i) abundant 
gabbro and ortho-amphibolites but almost absent felsic gneisses and (ii) $>70 \%$ of granitic gneisses and granites, respectively.

Carbonate rocks, occupying about $20 \%$ of the Olkhon terrane area, are mostly calcite marble and less abundant dolomite and calcite-dolomite marbles. They usually form linear bodies (layers) varying from tens of centimeters to tens of meters in thickness and several meters to tens of kilometers in length. Their intercalation with gneisses, amphibolites and mafic granulites gave reason to interpret the respective sequences as stratigraphically bedded volcanic-sedimentary formations. The sedimentary origin of numerous small (tens to hundreds of meters) bodies seemed beyond any doubt. However, detailed mapping (1:10000 and 1:12500 scales) and investigation of Baikal shore cliffs revealed carbonate bodies looking like intrusions: dykes of marble-like and silicate-carbonate rocks in gabbro and amphibolites [Sklyarov et al., 2013]. Rocks of this kind have their mineralogy and isotope geochemistry corresponding to sedimentary carbonate rather than to mantle-derived carbonatite but their geological relations with the coexisting rocks rather suggest intrusive or protrusive nature.

Such carbonate bodies are not unique and occur in other high-grade terranes, known as "marble dykes" from Norwegian Caledonides [Roberts, Zwaan, 2007], "crustal carbonatite" from the North China craton [Wan et al., 2008], and "carbonatite-like dykes" from the Eastern Himalayan Syntaxis [Liu et al., 2006]. Intrusive carbonate veins with crustal isotope signatures containing various xenoliths were described in the Khabarny mafic-ultramafic allochthone in the Urals [Fershtater, Pushkarev, 1988]. Their intrusive origin raises no doubt, but the very emplacement mechanism remains controversial with the choice between melt injection and highly mobile ductile flow. Being very interesting by itself in many aspects, this phenomenon has no value for regional geology though.

What is more important in terms of geological structure, is the presence of marble mélange in the Olkhon terrane first described by V.S. Fedorovsky more than twenty years ago [Fedorovsky et al., 1993]. Numerous bodies of marble mélange are highly variable in structure, thickness and composition of clasts which can be amphibolite, gneiss, mafic granulite, gabbro, or granite from few centimeters to several meters or tens of meters in size. Inclusions and blocks of silicate rocks may occupy about $50 \%$ of the mélange volume. The marble mélange makes part of thick marble layers or forms separate bodies of various sizes and configurations. The mélange bodies are found in almost all parts of the Olkhon terrane but are especially abundant in its northwestern (Tonta Zone) and southeastern (Krestovskaya Zone) parts. The marble mélange bodies differ markedly from the classical serpentine mélange zones in their morphology and geological position. Namely, serpentine mélange usually occurs at the base of ophiolite allochthones with a large amount of thrusting, while marble mélange forms during the emplacement of primary sedimentary carbonates mobilized by strike-slip tectonic events. Therefore, marble mélange carbonates are apparently the rocks displaced from their original position rather than in situ sedimentary layers.

The in situ position of ordinary marble "layers" is no less doubtful. Their length up to $30 \mathrm{~km}$ is poorly consistent with the mosaic structure of the terrane built as a collage of blocks that differ in the protolith composition and age [Donskaya et al., 2017]. Moreover, most of the marble "layers" coincide with blastomylonite sutures between the blocks. If most of them are allochthonous, the interpretation of the terrane structure would need revision, as well as the origin of the protolith for gneisses in the northwestern Olkhon terrane. Biotite gneiss, as well as rarer biotite-garnet and muscovite-biotite gneiss varieties, have been traditionally assumed to be metamorphosed clastic sediments, mainly proceeding from their visible intercalation with marbles. However, if the marble layers are allochthonous and mark tectonic sutures, removing them from the sequence would lead to a monotonous unit of gneisses with a granitic chemistry. Note that most gneisses usually look like granite gneiss and compositionally correspond to granite (or to granosyenite or granodiorite, to a lesser degree). Without the marble layers and complex tectonic zones in the northwestern terrane part, we obtain a large granite batholith more than $100 \mathrm{~km}$ long and about $20 \mathrm{~km}$ wide, or even wider, taking into account the linear geometry of all terrane structures. Some segments of the batholith, which are less strongly sheared (e.g., the Tutai granite massif and the SE Olkhon quartz syenite massif), have an age of $\sim 500$ Ma [Gladkochub et al., 2008; Donskaya et al., 2013], which may be the age of the whole batholith. If this interpretation is correct, two models of the Olkhon terrane structure are possible:

(1) the southeastern (mostly mafic) and northwestern (mostly granitic) segments of the terrane were originally the front and back parts of a Cambrian $(\sim 500$ Ma) magmatic arc which became dismembered and tectonically reworked during a collision at $470 \mathrm{Ma}$. Both mafic and granitic rock complexes have island arc geochemical affinities [Gladkochub et al., 2008; Donskaya et al., 2017];

(2) two segments originally belonged to different structures of the Paleoasian ocean (an island arc and a microcontinent) and were amalgamated during the collision.

As for the carbonate rocks of the terrane, some are a part of the metamorphic complex that hosts the batholith, together with quartzite and other metamorphosed 
sediments, but most of the carbonate and silicatecarbonate bodies (pseudo-layers) were injected into the batholith and other terrane parts from deeper levels. The presence of Early Precambrian rocks (1900-1800 Ma) as a protolith of granites in the Olkhon terrane has been confirmed by many studies (e.g. [Bibikova et al., 1980; Gladkochub et al., 2008; Donskaya et al., 2017]). It possibly was a fragment of the Siberian craton or some microcontinent on the Paleoasian ocean margin. Note that the Siberian craton and many composite terranes in the CAOB (Tuva-Monol, Dzabkhan et al.) contain thick Neoproterozoic carbonate sequences. If some continental block with a carbonate cover emplaced into the lower crust as a result of collision tectonics, carbonate rocks subject to high temperature and strong deformation became low viscous and produced ductile flow injected into the upper crust. Then, the carbonates involved into strike-slip motions may have formed pseudo-layers in any rock complexes, including the granite batholith.

\section{REFERENCES}

Bibikova E.V., Karpenko S.F., Sumin L.V., Bogdanovskii O.G., Kirnozova T.I., Lyalikov A.V., Makarov V.A., Arakelyants M.M., Korikovskii S.P., Fedorovskii V.S., Petrova Z.I., Levitskii V.I., 1990. U-Pb, Sm-Nd, Pb-Pb and K-Ar ages of metamorphic and igneous rocks of the Olkhon area (western Baikal region). In: V.M. Shemyakin (Ed.), Precambrian Geology and Geochronology of the Siberian craton and its surroundings. Nauka, Leningrad, p. 170-183 (in Russian).

Donskaya T.V., Gladkochub D.P., Fedorovsky V.S., Mazukabzov A.M., Cho M., Cheong W., Kim J., 2013. Synmetamorphic granitoids ( $\sim 490 \mathrm{Ma})$ as accretion indicators in the evolution of the Ol'khon terrane (western Cisbaikalia). Russian Geology and Geophysics 54 (10), 1205-1218. https://doi.org/10.1016/j.rgg.2013.09.006.

Donskaya T.V., Gladkochub D.P., Fedorovsky V.S., Sklyarov E.V., Cho M., Sergeev S.A., Demonterova E.I., Mazukabzov A.M., Lepekhina E.N., Cheong W., Kim J., 2017. Pre-collisional ( $0.5 \mathrm{Ga}$ ) complexes of the Olkhon terrane (southern Siberia) as an echo of events in the Central Asian Orogenic Belt. Gondwana Research 42, 243-263. https://doi.org/ 10.1016/j.gr.2016.10.016.

Fedorovsky V.S., Dobrzhinetskaya L.F., Molchanova T.V., Likhachev A.B., 1993. A new type of melange (Baikal, Olkhon region). Geotektonika (Geotectonics) 27 (4), 30-45 (in Russian).

Fedorovsky V.S., Sklyarov E.V., 2010. The Olkhon geodynamic proving ground (Lake Baikal): high resolution satellite data and geological maps of new generation. Geodynamics \& Tectonophysics 1 (4), 331-418 (in Russian). https:// doi.org/10.5800/GT-2010-1-4-0026.

Fershtater G.B., Pushkarev E.V., 1988. Carbonate rocks in the Kempirsai-Khabarny complex, the South Urals. Izvestiya AN SSSR, Seriya Geologicheskaya (12), 27-37 (in Russian).

Gladkochub D.P., Donskaya T.V., Wingate M.T.D., Poller U., Kröner A., Fedorovsky V.S., Mazukabzov A.M., Todt W., Pisarevsky S.A., 2008. Petrology, geochronology, and tectonic implications of c. 500 Ma metamorphic and igneous rocks along the northern margin of the Central-Asian Orogen (Olkhon terrane, Lake Baikal, Siberia). Journal of the Geological Society 165 (1), 235-246. https://doi.org/10.1144/0016-76492006-125.

Liu Y., Berner Z., Massonne H.J., Zhong D., 2006. Carbonatite-like dykes from the eastern himalayan syntaxis: geochemical, isotopic, and petrogenetic evidence for melting of metasedimentary carbonate rocks within the orogenic crust. Journal of Asian Earth Sciences 26 (1), 105-120. https://doi.org/10.1016/j.jseaes.2004.10.003.

Roberts D., Zwaan K.B., 2007. Marble dykes emanating from marble layers in an amphibolite-facies, multiply-deformed carbonate succession, Troms, Northern Norway. Geological Magazine 144 (5), 883-888. https://doi.org/10.1017/ S0016756807003810.

Sklyarov E.V., Fedorovsky V.S., Kotov A.B., Lavrenchuk A.V., Mazukabzov A.M., Starikova A.E., 2013. Carbonate and silicate-carbonate injection complexes in collision systems: the West Baikal region as an example. Geotectonics 47 (3), 180-196. https://doi.org/10.1134/S0016852113020064.

Wan Y., Liu D., Xu Z., Dong C., Wang Z., Zhou H., Yang Z., Liu Z., Wu J., 2008. Paleoproterozoic crustally derived carbonate-rich magmatic rocks from the Daqinshan area, North China craton: Geological, petrographical, geochronological and geochemical (Hf, Nd, O, and C) evidence. American Journal of Science 308 (3), 351-378. https://doi.org/ 10.2475/03.2008.07. 